\title{
Coil Embolization for Anterior Cerebral Artery Aneurysm : Anterior Communicating Artery Syndrome
}

\author{
Sung-Hak Kim · Sung-Kyun Hwang \\ Department of Neurosurgery, College of Medicine, Ewha Womans University \\ $=$ 국문조록 $=$ \\ 전교통 뇌동맥류 환자에 대한 코일색전술 치료 : 전교통뇌동맥 증후군 \\ 이화여자대학교 의학전문대학원 신경외과학교실 \\ 김 성 학.황 승 균
}

목 적 : 기존의 전교통 뇌동맥류에 대한 치료는 미세 결찰술이었지만, 최근에는 혈관내 코일색전술이 대 체 치료방법으로 증가추세에 있다. 하지만, 이 환자들의 치료 후 인지기능에 대하여 알려져 있는 바가 없 다. 본 연구의 목적은 전교통 뇌동맥류에 대한 코일색전술 후 인지기능의 평가를 하고자 한다.

방 법 : 2005년 6월부터 2010년 6월까지 본원에서 혈관내 코일색전술로 치료한 전교통 뇌동맥류 환자 36 명을 연구의 대상으로 삼았다. 이 연구의 모든 환자에게서 혈관내 코일색전술을 일차적인 치료를 하였다. 이 환자들에게 신경인지기능 평가와 임상적결과를 평가하였다.

결 과 : 임상신경학적으로 32 명 $(88 \%)$ 환자는 처음 상태와 비교하여 변화가 없거나 악화되지 않았으며, 4 명 $(12 \%)$ 환자에게서만 상태가 악화되었다. 그리고, 임상신경학적으로 악화된 4명의 환자를 포함하여 7 명 (19.4\%)에게서 인지기능의 문제가 발생하였다.

결 론 : 전교통 뇌동맥류 환자의 치료에 있어서 기역력, 실행력 등의 인지기능 장애가 흔히 발생하는 것으로 알려져 있다. 그러나, 인지기능 측면에서 비교하였을 경우, 본 연구의 결과는 전교통 뇌동맥류에 대 한 코일색전치료법이 우호적인 것임을 알 수 있다.

중심 단어 : 코일색전술·전교통 뇌동맥류 · 인지기능.

\section{Introduction}

Of all brain aneurysms, the ACoA aneurysm is the most frequent ${ }^{4) 1121125(28) 2930)}$. Due to the deep, midline location of these aneurysms and to the number of impor-

Address for correspondence: Sung-Kyun Hwang, MD Department of Neurosurgery, Mokdong Hospital, 911-1 Yangcheon-gu, Seoul 158-710, Korea

Tel : (02) 2650-2872·전송 : (02) 2650-0948

E-mail : nshsg@ewha.ac.kr tant small branches and perforating vessels arising from the $\mathrm{ACoA}$, their surgical treatment remains an arduous task. In recent years the endovascular approach to ACoA aneurysms has emerged as an inherently less traumatic alternative treatment option.

A number of recent technical developments have ameliorated the results and the feasibility of endovascular treatment of ACoA aneurysms. The improved coatings in microcatheters and guidewires improved the efficacy and safety in the catheterization of brain aneurysms. The development of tridimensional coils improved the device 
anchoring and produced a more homogeneous aneurysm embolization in small and large wide necked aneurysms. The introduction of rotational digital angiography improved the anatomical and geometrical information, the catheter localization, the coil selection, the angle of embolization, and the anatomical outcome. As a consequence, it also decreased technical and clinical complications. The use of the balloon-assisted technology in ruptured and unruptured aneurysms, and the use of stents in unruptured aneurysms are particularly effective in large and wide-necked lesions, with a very low rate of iatrogenic complications ${ }^{2557)(8) 16) 22(25) 26) 32)}$. We present our experience in the endovascular management of 36 consecutive patients harboring an ruptured ACoA aneurysm.

\section{Patients and Methods}

\section{Patients}

A series of consecutive 36 patients harboring an ACoA aneurysm were treated at our institutions via the endovascular approach between January 2005 and June 2010. All patients underwent conventional angiography of both carotid arteries. In 2 cases, which were not included in this series, the endovascular treatment was attempted but failed, with no adverse clinical consequences. These failure cases occurred early in our experience. The selection criteria for this study were : 1) spontaneous subarachnoid hemorrhage (aneurysm rupture as the cause of subarachnoid hemorrhage) between January 2005 and June 2010, 2) endovascular aneurysm treatment chosen as the first line of treatment, and 3) that aneurysm repair treatment was given at the acute stage after hemorrhage(within 3 weeks of aneurysm rupture) 4) patients with fusiform, traumatic, or mycotic aneurysm were excluded from the study. In this series, 18 were females $(50 \%)$ and $18(50 \%)$ were males. The patients' ages ranged from 29 to 81 years, with an average age of 52.5 years.

\section{Aneurysm characteristics}

Regarding the aneurysm size, 3 lesions $(8 \%)$ were small ( $<3 \mathrm{~mm}$ in diameter), 31 lesions $(86 \%$ ) were medium(3$15 \mathrm{~mm}$ in diameter), 1 lesion(2\%) was large(15-25 mm in diameter), and $1(2 \%)$ was giant $(>25 \mathrm{~mm}$ in diameter). Regarding the aneurysm neck size, 32 lesions $(89 \%)$ had a small neck $(\leq 4 \mathrm{~mm})$, whereas 4 lesions(11\%) had a wide neck( $>4 \mathrm{~mm})$. Thirty-four(94\%) aneurysms were smaller than $15 \mathrm{~mm}$.

\section{Clinical presentation}

All patients presented with a subarachnoid hemorrhage. Of these, One patient(2\%) was categorized in Hunt and Hess Grade I, 21(58\%) in Grade II, 13(36\%) in Grade III, and $1(2 \%)$ in Grade IV.

\section{Follow up \& cognitive outcome}

After embolization, all patients were followed up at least 6 months. The cognitive outcome of all patients treated by embolization was assessed 6 months after treatment according to patient's conditions. The cognitive outcome was evaluated by experienced neurologist on general mental state, verbal memory, visual memory, executive function, and language function

\section{Endovascular embolization procedure}

Coiling of aneurysms was performed on a biplane angiographic unit (Integris BN 3000 ; Phillips Medical Systems, Best, the Netherlands). Embolization was performed after induction of general anesthesia and systemic heparinization(3000 IU bolus, followed by continuous intraarterial infusion of heparin at $1000 \mathrm{IU} /$ hour) and maintenance of an activated coagulation time more than twice the control value. Aneurysms were embolized using size 10 soft GDCs(Guglielmi detachable coils, Boston Scientific, Boston, USA) 2 or $3 \mathrm{~mm}$ in diameter. After road mapping was performed using clear magnified images, a microcatheter(Excelsior SL-10 ; Boston Scientific, Boston, USA or Prowler 14 ; Cordis, Miami, USA) was carefully inserted into the aneurysm over the guidewire, and coils were then introduced. The aim of coiling was obtain an attenuated packing of the aneurysm, until not a single coil could be placed. In the occurrence of aneurysm perforation during coiling, heparin was reversed instantaneously and coiling was continued until the bleeding stopped. In the occurrence of thromboembolic complications. usually a selective bolus injection of 100,000-250,000 $\mathrm{U}$ of urokinase was administered in the involved vessel, followed from 2002 onward by intravenous infusion of a glycoprotein IIb/IIIa antagonist(tirofiban ; Aggrastat, Merck \& Co., USA), titrated to 2 to 3 times normal values of activated thromboplastin time. After embolization, an- 
ticoagulation therapy was stopped.

\section{Results}

\section{Treatment results}

A complete aneurysm occlusion was attained in 27 cases $(75 \%)$. A neck remnant was detected in 6 cases $(16 \%)$ and in $3(8 \%)$ a residual filling of a portion of the aneurysm was observed. Satisfactory occlusion rate(complete occlusion or neck remnant) was achieved in $92 \%$ of patients. In 1 case $(2 \%)$ the aneurysm was perforated during the procedure. This hemorrhage was immediately stopped by delivering additional coils and reversing the anticoagulation therapy. Therefore, the procedure-related morbidity rate was $2 \%(1$ case $)$.

\section{Clinical outcome(cognitive function)}

Regarding the clinical neurological outcome, 32 patients $(88 \%)$ remained neurologically intact, improved or unchanged from initial clinical status. The posttreatment clinical examination showed worse in 4 cases(12\%). Among those who had endovascular embolization, 7 patients including 4 cases with worse neurological state(19.4\%) showed impairments on memory and executive function.

\section{Discussion}

\section{Endovascular series}

In 2002 Kazekawa et al. ${ }^{16)}$ presented the overall clinical and angiographic evaluation in 19 consecutive patients with ACoA aneurysms who were treated with GDCs. Complete obliteration was obtained in $68 \%$ of cases, whereas a neck remnant was observed in $32 \%$. Regarding the overall clinical outcome, 3 patients( $15 \%$ ) who were originally categorized in Grades IV and V died, 1(5\%) was moderately disabled, and $15(80 \%)$ had a good recovery. The authors pointed out that the patients, who had a good recovery did not demonstrate significant personality or behavioral changes.

In 1996, Moret et al. ${ }^{22)}$ published the results of endovascular treatment in $36 \mathrm{ACoA}$ aneurysms. In 7 of these cases $(20 \%)$ the treatment failed. This high rate of failure can be explained because the technical armamentarium in the mid-1990s was not as advanced and sophisticated as it is today. Of the 29 treated aneurysms, it was possible to achieve a complete occlusion in $23(79 \%)$, whereas the occlusion was only partial (neck remnant) in the remaining 6 cases $(21 \%)$. These investigators observed a postprocedural temporary neurological deficit in 2 cases, and the procedure-related permanent morbidity was $3.5 \%$ (1 case). No procedure-related death was reported. Tsutsumi et al. ${ }^{33)}$ reported on the overall results in 19 ruptured tiny (diameter $\leq 3 \mathrm{~mm}$ ) ACoA aneurysms. Sixteen patients presented in Grades I-III, and 3 cases were categorized in Grade IV. Complete aneurysm occlusion was obtained in $84 \%$ of cases, whereas near-complete occlusion was obtained in $16 \%$ of cases. In 15 patients( $79 \%)$ the outcome was good, whereas in 3 cases $(16 \%)$ the clinical follow-up showed severe disability, and 1 patient (5\%) died of severe vasospasm. None of the 18 patients who were followed clinically for a median period of 39.5 months showed rebleeding. Proust et al. ${ }^{25226)}$ conducted a study in which the ACoA aneurysms were divided into 3 groups. In Group A, clip application was performed regardless of whether the aneurysm fundus was directed anteriorly or posteriorly. In Group B, clip application was performed only in aneurysms, that were anteriorly directed. In Group C(37 cases), the aneurysms were treated endovascularly with coil occlusion. In this latter group, the investigators observed identical morbidity and mortality rates $(8 \%)$. These rates compare unfavorably with the results of our and others' series. Proust et al. concluded that anteriorly directed ACoA aneurysms should be surgically clipped, whereas posteriorly directed $\mathrm{ACoA}$ aneurysms should be treated with coils. This was recommended because all the ACoA branches and perforating vessels arise from the posterior aspect of the artery. In our series, satisfactory occlusion rate(complete occlusion or neck remnant) was achieved in $92 \%$ of patients comparing with previous series.

\section{Anatomy of the ACoA}

The ACoA has a diameter ranging from 0.8 to $3.4 \mathrm{~mm}$, and a length of 0.8 to $4.6 \mathrm{~mm}$. There are several branches arising from the artery : in autopsy studies, the number of these branches ranged from 3 to 13, with an average of 6. Two studies ${ }^{915)}$ showed that the ACoA branches are small and large, all arising from the posterior aspect 
of the artery. The small branches were $1-5$ in number and $70-270 \mu \mathrm{m}$ in diameter, while the largest branch was the subcallosal artery. This artery had a bilateral termination in the subcallosal areas, which includes the rostrum and genu of the corpus callosum, the anterior commissure, the anterior cingulate gyri, the paraolfactory gyri, the paraterminal gyri, the anterior septum pellucidum, and the column of the fornix. Impairment of the ACoA branches is reported to cause memory disturbances and personality changes ${ }^{3) 6(2) 20) 23 / 24) 31 \text { ). }}$

\section{The "ACoA Syndrome"}

Rupture alone, or surgical repair of an ACoA aneurysm may result in cognitive deficits such as memory impairment and personality changes, which are usually referred to as the "ACoA syndrome"1)10)13)14)18)19)27). Even patients with a postoperative Glasgow Outcome Scale score of 4 or 5 may still exhibit significant cognitive deficits $^{10)}$. One study ${ }^{17)}$ evaluated the quality of life and the degree of cognitive dysfunction in 93 patients 4.5 years after surgery of a ruptured brain aneurysm ; patients with an ACoA aneurysm were more likely to suffer cognitive dysfunctions than patients who had a ruptured aneurysm elsewhere in the intracranial vasculature. The only study that compares the cognitive outcome between surgically and endovascularly treated patients was published by Chan et al. ${ }^{5)}$. In this study, neuropsychological tests were used to assess the cognitive function in 18 patients with a ruptured ACoA aneurysm. Half of them had undergone surgical clip application and the other half had endovascular embolization. The patients treated with coil embolization showed significantly fewer severe cognitive deficits than those who had undergone surgical clip application. Cognitive deficits commonly observed in ACoA patients include memory : although immediate recall may be relatively intact or modestly impaired a significant deficit appears on tests assessing delayed recall for verbal or visuo-spatial information. In contrast with amnesic subjects, where the damage is diencephalic and mesial temporal, ACoA patients show a more severe impairment in recall than in recognition tasks, due to basal forebrain damage. In our series, regarding the clinical neurological outcome, 32 patient $(88 \%)$ remained neurologically intact, improved or unchanged from initial clinical status. The posttreatment clinical examination showed worse in 4 cases $(12 \%)$. Theses results favored the coil embolization of ACoA aneurysm in terms of cognitive function over surgical clipping.

\section{Conclusion}

From the results of this series and from the review of the literature it is possible to infer that the endovascular treatment of ACoA aneurysms has a definite place in the treatment of these complex lesions. Recent technical developments have improved the safety and efficacy of endovascular treatment. From the data of the literature it is possible to deduce that postsurgical personality and memory disturbances seem less likely to occur in patients treated using the endovascular procedure. The inherently lower risk of injuring the delicate branches and perforating vessels arising from the ACoA makes the endovascular approach attractive, interesting, and elegant.

\section{References}

1) Bavinzski G, Talazoglu V, Killer M, Richling B, Gruber A, Gross CE, et al : Gross and microscopic histopathological findings in aneurysms of the human brain treated with Guglielmi detachable coils. J Neurosurg 1999 ; 91 : 284-293, 1999

2) Bellebaum C, Schäfers L, Schoch B, Wanke I, Stolke D, Forsting M, et al : Clipping versus coiling : neuropsychological follow up after aneurysmal subarachnoid haemorrhage (SAH). J Clin Exp Neuropsychol 2004 ; 26 : 1081-1092, 2004

3) Böttger S, Prosiegel M, Steiger HJ, Yassouridis A : Neurobehavioural disturbances, rehabilitation outcome, and lesion site in patients after rupture and repair of anterior communicating artery aneurysm. J Neurol Neurosurg Psychiatry 1998; 65 : 93-102

4) Bryan RN, Rigamonti D, Mathis JM : The treatment of acutely ruptured cerebral aneurysms : endovascular therapy versus surgery. AJNR Am J Neuroradiol 1997 ; 18 : 1826-1830

5) Chan A, Ho S, Poon WS : Neuropsychological sequelae of patients treated with microsurgical clipping or endovascular embolization for anterior communicating artery aneurysm. Eur Neurol 2004 ; 47 : 37-44 
6) Diamond BJ, DeLuca J, Kelley SM : Memory and executive functions in amnesic and non-amnesic patients with aneurysms of the anterior communicating artery. Brain 1997 ; 120 : 1015-1025

7) Fontanella M, Perozzo P, Ursone R, Garbossa D, Bergui $\mathrm{M}$ : Neuropsychological assessment after microsurgical clipping or endovascular treatment for anterior communicating artery aneurysm. Acta Neurochir (Wien) 2003 ; 145 : 867-872; discussion 872

8) Frazer D, Ahuja A, Watkins L, Cipolotti L : Coiling versus clipping for the treatment of aneurysmal subarachnoid hemorrhage : a longitudinal investigation into cognitive outcome. Neurosurgery 2007 ; 60 : 434-441 ; discussion 441-442

9) Gruber DP, Zimmerman GA, Tomsick TA, van Loveren HR, Link MJ, Tew JM Jr : A comparison between endovascular and surgical management of basilar artery apex aneurysms. J Neurosurg 1999 ; 90 : 868-874

10) Hadjivassiliou M, Tooth CL, Romanowski CA, Byrne J, Battersby RD, Oxbury S, et al : Aneurysmal SAH: cognitive outcome and structural damage after clipping or coiling. Neurology $2001 ; 26: 1672-1677$

11) Hayakawa M, Murayama Y, Duckwiler GR, Gobin YP, Guglielmi G, Viñuela F : Natural history of the neck remnant of a cerebral aneurysm treated with the Guglielmi detachable coil system. J Neurosurg 2000 ; 93 : 561-568

12) Hillis AE, Anderson N, Sampath P, Rigamonti D : Cognitive impairments after surgical repair of ruptured and unruptured aneurysms. J Neurol Neurosurg Psychiatry $2000 ; 69: 608-615$

13) Hop JW, Rinkel GJ, Algra A, van Gijn J : Changes in functional outcome and quality of life in patients and caregivers after aneurysmal subarachnoid hemorrhage. J Neurosurg 2001 ; 95 : 957-963

14) Hop JW, Rinkel GJ, Algra A, van Gijn J : Quality of life in patients and partners after aneurysmal subarachnoid hemorrhage. Stroke 1998 ; 29 : 798-804

15) Hütter BO, Kreitschmann-Andermahr I, Gilsbach JM : Health-related quality of life after aneurysmal subarachnoid hemorrhage: impacts of bleeding severity, computerized tomography findings, surgery, vasospasm, and neurological grade. J Neurosurg 2001 ; 94 : 241-251

16) Kazekawa K, Tsutsumi M, Aikawa H, Iko M, Tanaka A, Go Y, et al : Endovascular treatment of anterior cerebral artery aneurysms using Guglielmi detachable coils : mid-term clinical evaluation. Radiat Med $2002 ; 20$ : 291-297

17) Kreiter KT, Copeland D, Bernardini GL, Bates JE, Peery
S, Claassen J, et al : Predictors of cognitive dysfunction after subarachnoid hemorrhage. Stroke 2002 ; 33 :200-208

18) Mavaddat N, Kirkpatrick PJ, Rogers RD, Sahakian BJ : Deficits in decision-making in patients with aneurysms of the anterior communicating artery. Brain 2000; 123 : 2109-2117

19) Mavaddat N, Sahakian BJ, Hutchinson PJ, Kirkpatrick PJ : Cognition following subarachnoid hemorrhage from anterior communicating artery aneurysm : relation to timing of surgery. J Neurosurg 1999 ; 91 : 402-407

20) Mayer SA, Kreiter KT, Copeland D, Bernardini GL, Bates JE, Peery S, et al : Global and domain-specific cognitive impairment and outcome after subarachnoid hemorrhage. Neurology 2002 ; 10 : 1750-1758

21) Molyneux AJ, Kerr RS, Yu LM, Clarke M, Sneade M, Yarnold JA, et al : International subarachnoid aneurysm trial (ISAT) of neurosurgical clipping versus endovascular coiling in 2143 patients with ruptured intracranial aneurysms : a randomised comparison of effects on survival, dependency, seizures, rebleeding, subgroups, and aneurysm occlusion. Lancet $2005 ; 366$ : 809-817

22) Moret J, Pierot L, Boulin A, Castaings L, Rey A : Endovascular treatment of anterior communicating artery aneurysms using Guglielmi detachable coils. Neuroradiology $1996 ; 38: 800-805$

23) Nathal E, Yasui N, Sampei T, Suzuki A : Intraoperative anatomical studies in patients with aneurysms of the anterior communicating artery complex. J Neurosurg 1992 ; $76: 629-634$

24) Powell J, Kitchen N, Heslin J, Greenwood R : Psychosocial outcomes at 18 months after good neurological recovery from aneurysmal subarachnoid haemorrhage. J Neurol Neurosurg Psychiatry 2004 ; 75 : 1119-1124

25) Proust F, Debono B, Hannequin D, Gerardin E, Clavier E, Langlois $\mathrm{O}$, et al : Treatment of anterior communicating artery aneurysms : complementary aspects of microsurgical and endovascular procedures. J Neurosurg $2003 ; 99: 3-14$

26) Proust F, Martinaud O, Gérardin E, Derrey S, Levèque $\mathrm{S}$, Bioux S, et a : Quality of life and brain damage after microsurgical clip occlusion or endovascular coil embolization for ruptured anterior communicating artery aneurysms : neuropsychological assessment. J Neurosurg $2009 ; 110: 19-29$

27) Raaymakers TW : Functional outcome and quality of life after angiography and operation for unruptured intracranial aneurysms. On behalf of the MARS Study Group. 
J Neurol Neurosurg Psychiatry 2000 ; 68 : $571-576$

28) Sengupta RP, Chiu JS, Brierley H : Quality of survival following direct surgery for anterior communicating artery aneurysms. J Neurosurg 1975 ; 43 : 58-64

29) Solheim O, Eloqayli H, Muller TB, Unsgaard G : Quality of life after treatment for incidental, unruptured intracranial aneurysms. Acta Neurochir(Wien) $2006 ; 148$ : 821-830; discussion 830

30) Solomon RA : Anterior communicating artery aneurysms. Neurosurgery 2001 ; 48 : 119-123

31) Stenhouse LM, Knight RG, Longmore BE, Bishara SN :
Long-term cognitive deficits in patients after surgery on aneurysms of the anterior communicating artery. J Neurol Neurosurg Psychiatry 1991 ; 54 : 909-914

32) Tidswell P, Dias PS, Sagar HJ, Mayes AR, Battersby $\mathrm{RD}$ : Cognitive outcome after aneurysm rupture : relationship to aneurysm site and perioperative complications. Neurology 1995 ; 45 : 875-882

33) Tsutsumi M, Aikawa H, Onizuka M, Kodama T, Nii K, Matsubara $\mathrm{S}$, et al : Endovascular treatment of tiny ruptured anterior communicating artery aneurysms. Neuroradiology 2008 ; $50: 509-515$ 